\title{
Optimized cyclosporine starting dose may reduce risk of acute GvHD after allogeneic hematopoietic cell transplantation: a single-center cohort study
}

\author{
Jérémie Héritier ${ }^{1,2}$, Michael Medinger (iD ${ }^{1,2,3}$, Dominik Heim ${ }^{1,2}$, Helen Baldomero (D) $^{1,2}$, Christian Arranto ${ }^{1,2}$, Jörg P. Halter (iD ${ }^{1,2}$, \\ Jakob R. Passweg ${ }^{1,2}$ and Martina Kleber (iD ${ }^{1,2,3 凶}$
}

(c) The Author(s) 2022

\begin{abstract}
Cyclosporine A (CsA) is commonly used for Graft versus Host Disease (GvHD) prophylaxis at a recommended starting dose of 3 mg/ $\mathrm{kg} / \mathrm{d}$ : Evidence for the effect of different CsA starting doses on GvHD risk is limited. We therefore estimated the association of $5 \mathrm{mg} /$ $\mathrm{kg} / \mathrm{d}$ (CsA5) and $3 \mathrm{mg} / \mathrm{kg} / \mathrm{d}$ (CsA3) CsA starting doses with GvHD risk in two consecutive cohorts of allogeneic hematopoietic cell transplantation (allo-HCT) patients, exploring potential risk factors for incident acute GvHD, with a focus on CsA starting dose. We analyzed 519 patients within CsA5 $(n=153)$ and CsA3 $(n=366)$. The cumulative incidence function of acute GvHD grade $\geq 2$ was higher in the CsA3 compared to the CsA5 group ( $41 \%$ vs. $33 \%$, respectively; $p=0.043)$, without impacting chronic GvHD. In multivariable analysis, a CsA starting dose of $3 \mathrm{mg} / \mathrm{kg} / \mathrm{d}$, no ATG use, unrelated donor and high to very high disease risk index were significantly associated with acute GvHD grade $\geq 2$. A higher CsA starting dose of $5 \mathrm{mg} / \mathrm{kg} / \mathrm{d}$ was independently associated with lower acute GvHD risk, and higher CsA levels in the early period after allo-HCT were reached.
\end{abstract}

Bone Marrow Transplantation (2022) 57:613-619; https://doi.org/10.1038/s41409-022-01598-6

\section{INTRODUCTION}

Allogeneic hematopoietic cell transplantation (allo-HCT) offers a potential curative option for various hematological disorders [1-3], but is associated with significant morbidity and mortality [4, 5]. Acute (aGvHD) and chronic GvHD (cGvHD)-an alloreactivity against host antigens - is linked to morbidity and mortality after allo-HCT, limiting its beneficial effects [6-14]. Relevant risk factors for the development of GvHD are the patient age, donor type and HLA mismatch, stem cell source, donor-recipient sex constellation, disease activity, CMV serostatus, conditioning regimen and GvHD prophylaxis [15-19].

Cyclosporine (CsA), a calcineurin-inhibitor, is a commonly used drug for GvHD prophylaxis [20, 21]. Initial dosing, timing of CsA application, target CsA blood level concentrations and schedule of administration remains variable [22-34]. Optimal CsA dosing may be of importance as higher incidence of GvHD has been in previous studies associated with lower CsA exposure and that high CsA levels were associated with more graft failures in RIC transplants [14]. The recommended standard CsA starting dose by the EBMT handbook and used since the first clinical trials establishing the combination of $\mathrm{CsA}$ with methotrexate as standard GvHD prophylaxis is $3 \mathrm{mg} / \mathrm{kg}[34,35]$. Previously, we could demonstrate that close monitoring of $\mathrm{CsA}$ dosing with active adjustments to maintain therapeutic CsA levels $>195 \mu \mathrm{g} / \mathrm{L}$ in the first 10 days after allo-HCT significantly may reduce the incidence of aGvHD [36]. It is unclear however, if higher CsA starting doses affect post-allo-HCT CsA levels and GvHD risk [22, 27, 36, 37].
Following the analysis of our previously published data, we changed starting dose from $3 \mathrm{mg} / \mathrm{kg}$ to $5 \mathrm{mg} / \mathrm{kg}$ over $6 \mathrm{~h}$ intravenously (i.v.) [36]. Here we report the potential impact of this measure on clinical outcomes.

\section{MATERIAL AND METHODS}

\section{Patient population and study design}

This single-center cohort study included consecutive patients from the Department of Hematology of the University Hospital of Basel with (i) hematological diseases who had (ii) their first allo-HCT between January 2010 and October 2018. Patients with a CsA starting dose of $3 \mathrm{mg} / \mathrm{kg} / \mathrm{d}$ from January 2010 to June 2016 were compared to patients who received consecutively a starting dose of $5 \mathrm{mg} / \mathrm{kg} / \mathrm{d}$ CsA from June 2016 to October 2018.

We extracted relevant patient and disease characteristics from our electronic research database-including sex, age, HCT pretransplant risk scores (Karnofsky Performance Status [KPS], European Group for Blood and Marrow Transplantation [EMBT] score [38], Hematopoietic Cell Transplantation Comorbidity Index [HCT-Cl] [39], disease risk index [DRI] [40]), and the interval diagnosis to allo-HCT. Allogeneic HCT characteristics include CMV status, donor type (HLA match/mismatch, related/unrelated), conditioning regimen, GvHD prophylaxis, stem cell source and CD34+ cell dose. Serum creatinine and estimated glomerular filtration rate (eGFR) by the CDK-EPI (Chronic Kidney Disease Epidemiology Collaboration) equation [41] were measured on day 0 (time of HCT) and on day 7 after HCT [42]. The study was approved by the Ethics Committee of Northwestern and Central Switzerland (EKNZ study number: 2018-02000). All patients provided their informed consent for further use of their data for research purposes.

\footnotetext{
${ }^{1}$ University Hospital Basel, Division of Hematology, Basel, Switzerland. ${ }^{2}$ University of Basel, Basel, Switzerland. ${ }^{3}$ University Hospital Basel, Department of Internal Medicine, Basel, Switzerland. ${ }^{凶}$ email: martina.kleber@usb.ch
}

Received: 29 January 2021 Revised: 21 January 2022 Accepted: 24 January 2022

Published online: 8 February 2022 
The primary outcome of this study was incident aGvHD grade $\geq 2$ following a first allo-HCT in patients with CsA starting dose of $3 \mathrm{mg} / \mathrm{kg} / \mathrm{d}$ compared $5 \mathrm{mg} / \mathrm{kg} / \mathrm{d}$. Secondary outcome measures were 1 -year progression-free (PFS) and -overall survival (OS), and the incidence of 1-year nonrelapse-mortality (NRM) and -relapse.

\section{Graft-versus-host disease prophylaxis and conditioning regimens}

Myeloablative conditioning (MAC) protocols consisted of cyclophosphamide combined with busulfan, cyclophosphamide and total body irradiation $(\mathrm{TBI}) \geq 8$ Gray, cytarabine, carmustine, etoposide, melphalan, and fludarabine (BEAM- fludarabine) and other protocols [36].

Reduced-intensity conditioning (RIC) protocols consisted of fludarabine with low-dose $\mathrm{TBI}<6 \mathrm{~Gy}$, fludarabin combined with busulfan or melphalan, and other protocols. Reasons for RIC were relevant comorbidities or advanced age [36].

Within MAC conditioning regimens, GvHD prophylaxis consisted of CsA and methotrexate (MTX) as well as anti-thymocyte globulin (ATG) in case of unrelated donors and in matched related donors $\geq 40$ years [43] or other protocols: CsA was administered in a dose of $3 \mathrm{mg} / \mathrm{kg} / \mathrm{day}$ and $5 \mathrm{mg} / \mathrm{kg} /$ day i.v. starting day-3 (in BEAM-fludarabin protocols on day $-1, n=20$ ) before allo-HCT. Antit-hymocyte globulin (rabbit) was used in the dose of $5 \mathrm{mg} / \mathrm{kg} / \mathrm{d}$ (day-3), $10 \mathrm{mg} / \mathrm{kg} / \mathrm{d}$ (day -2) and $20 \mathrm{mg} / \mathrm{kg} / \mathrm{d}$ (day -1) as previously described (Grafalon, Neovii ${ }^{\circledR}$ ) [43]. GvHD prophylaxis in patients with RIC conditioning regimens included CsA, MTX, and ATG in patients with unrelated donors and matched related donors $\geq 40$ years (if RIC included fludarabin/busulfan), or CsA from day -1 and mycophenolat mofetil (MMF) if RIC was based on fludrarabin/low-dose TBI [36]. The measurement of CsA blood concentration was done as trough levels by high-performance liquid chromatography (HPLC) at least weekly, and in addition two days after dose changes. Target levels were $150-200 \mu \mathrm{g} / \mathrm{L}$ as per EBMT recommendations [35] with both CsA starting doses of $3 \mathrm{mg} / \mathrm{kg} /$ $\mathrm{d}$ and $5 \mathrm{mg} / \mathrm{kg} / \mathrm{d}$. During the post-allo-HCT period, CsA was changed from i.v. to oral (per os) given adequate oral intake and thereafter tapered and stopped 180 days after HCT in the absence of aGvHD.

\section{GvHD diagnosis and therapy}

Acute GvHD was graded according to the modified Glucksberg criteria [44] and CGvHD was graded based on the revised Seattle criteria [45]. In case of clinical relevant GvHD grade $\geq 2$, patients were treated with corticosteroids i.v. (methylprednisolone, $2 \mathrm{mg} / \mathrm{kg} / \mathrm{d}$ ). The definition of corticosteroid resistance was defined by no response after 7 days of treatment or clear progression after five days [46].

\section{Statistical analysis}

Continuous variables were reported as median (interquartile range [IQR]). We assessed differences in demographic, clinical, and transplantation parameters using Chi-squared or Fisher's exact test for categorical variables and Student's $t$-test or Mann-Whitney $U$ test for continuous variables, depending on data distributions. Categorical variables were presented as proportions. The cumulative incidence function of one-year NRM and relapse/progression were estimated by accounting for competing events. To study GvHD, death or relapse were considered as competing events. Probabilities of PFS and OS were estimated using the Kaplan-Meier estimator at one year.

We analyzed CsA starting doses of $3 \mathrm{mg} / \mathrm{kg} / \mathrm{d}$ and $5 \mathrm{mg} / \mathrm{kg} / \mathrm{d}$ in a multivariable model. Risk factors for aGvHD grade $\geq 2$ were investigated by fitting univariable and multivariable subdistribution proportional hazards models by Fine\&Gray; co-variables included the CsA starting doses of 3 $\mathrm{mg} / \mathrm{kg} / \mathrm{d}$ and $5 \mathrm{mg} / \mathrm{kg} / \mathrm{d}$, ATG vs. non-ATG based GvHD prophylaxis, donor/ recipient gender, disease risk index, donor age, graft source, donor type and conditioning regimens [47]. In the final multivariable analysis, only significant confounders (at univariable $p<0.05$ ) were included. For each patient, follow-up was calculated from HCT until death from any cause or last follow-up (censoring of survivors).

Above computations relied on standard software (SPSS Statistics V25 IBM, Chicago, IL, USA; Stata SE v16 StataCorp LLC, College Station, TX, USA). All $p$ values are two-sided and $p<0.05$ was considered statistically significant.

\section{RESULTS}

\section{Patient characteristics}

During the study period, 632 patients underwent an allo-HCT. Exclusion criteria are patients less than 18 years old $(n=30)$, GvHD prophylaxis with posttransplant cyclophosphamide on day +3 and $+4 \quad(n=31$ haploidentical donors and $n=23$ mismatched unrelated donors) and therefore CsA start on day +5 after alloHCT or no CsA application $(n=13)$. Moreover, patients with bone marrow failure $(n=13)$ and cord blood graft source $(n=3)$ were excluded from the analyses. Of these, 113 patients were excluded because of mentioned exclusion criteria and 519 patients were included in the final analysis. The patient- and transplant-related characteristics are described in Table 1: The median age of the entire patient cohort was 54 years (IQR, 43-63 years). The most common underlying hematological disease was myeloid neoplasm (67\%), followed by lymphoid malignancies (33\%). Three hundred sixty-six (71\%) patients received a CsA starting dose of 3 $\mathrm{mg} / \mathrm{kg} / \mathrm{d}$ and 153 (29\%) patients a starting dose of $5 \mathrm{mg} / \mathrm{kg} / \mathrm{d}$. Patients in the CsA3 group compared to the CsA5 group were significantly younger with a median age of 53 years (IQR, 43-62 years) vs. median of 57 years (IQR, 44-65 years), respectively. Main hematological diseases were myeloid malignancies and significantly higher in the CsA5 groups $(80 \%$ vs. $62 \%$, respectively; $p<$ $0.001)$. The DRI with intermediate to very high within CsA3 vs. CsA5 group was $82 \%$ vs. $75 \%$, respectively $(p=0.002)$. Mostly frequently used conditioning regimens were myeloablative with $75 \%$ in the CsA3 compared to $60 \%$ in the CsA5 group $(p<0.001)$. In line, TBI was more frequently applied in the CsA3 group compared to the CsA5 group ( $p=0.002$ ). Whereas no differences were seen according donor type in both CsA starting dose groups. In line, frequencies of allo-HCT from 10/10 HLA-identical donor were comparable in both CsA groups (82\% in the CsA3 group vs. $85 \%$ in the CsA5 group). Stem cell source was mainly peripheral blood and balanced in both CsA starting doses. At baseline, the median eGFR levels according to the CKD-EPI formula in the CsA3 vs. CsA5 group was $105 \mathrm{ml} / \mathrm{min} / 1.73 \mathrm{~m}^{2}$ (IQR, $92-117 \mathrm{ml} / \mathrm{min} /$ $\left.1.73 \mathrm{~m}^{2}\right)$ vs. $101 \mathrm{ml} / \mathrm{min} / 1.73 \mathrm{~m}^{2}$ (IQR, $84-114 \mathrm{ml} / \mathrm{min} / 1.73 \mathrm{~m}^{2}, p$ value $=0.059$ ), respectively (Supplementary Table S1). Accordingly, patients with CKD stages 1 vs. 2 vs. 3 were evident in $79 \%$ vs. $16 \%$ vs. $5 \%$, respectively in the CsA3 groups compared to $70 \%$ vs. $24 \%$ and $6 \%$, respectively, in the CsA5 group. There was no initial need to perform starting dose adjustments (only in case of renal toxicity during the course of post-transplantation period). In line, in patients with higher CsA starting doses no clinical relevant decrease in renal function after seven days post HCT could be observed (Supplementary Table S1).

The median follow-up of all surviving patients was 1153 days (IQR 580-1,861 days). The median follow-up for patients within the CsA5 cohort vs. CsA3 cohort was 565 days (IQR 239-719) vs. 1,661 days (IQR 1,293-2,197 days), respectively.

\section{Cumulative incidence function and risk factors for acute GvHD and chronic GvHD}

The CIF of aGvHD grade $\geq 2$ was higher in patients within the CsA3 compared to the CsA5 group (41\% [95\% Cl: 36-46\%] vs. 33\% [95\% Cl: $26-40 \%]$, respectively; $p=0.043$, Table 2, Fig. 1). Additional analyses of CIF of aGvHD grade III-IV in the CsA3 vs. CsA5 cohort were performed: the results revealed that more patients in the CsA3 cohort showed a higher CIF of aGvHD III-IV with 15\% (95\% $\mathrm{Cl}: 12-19 \%)$ compared to patients in the CsA5 (CIF of aGvHD grade III-IV of $10 \% ; 95 \% \mathrm{Cl}: 6-15 \%)$, respectively. Albeit the analysis of aGvHD grade III-IV failed to reach statistical significance ( $p=$ 0.082 ) probably due to the limited statistical power of patients with aGvHD grade III-IV, the analysis also confirm that higher starting of $5 \mathrm{mg} / \mathrm{kg} / \mathrm{d}$ could also reduce the incidence of aGvHD grade III-IV (Table 2). Following an allo-HCT, there was no significant difference in one-year CIF of CGvHD in patients with $3 \mathrm{mg} / \mathrm{kg} / \mathrm{d}$ vs. $5 \mathrm{mg} / \mathrm{kg} / \mathrm{d}$ (41\% [95\% Cl: $36-46 \%$ ] vs. $38 \%$ [95\% Cl: 30-46\%], respectively; $p=0.792$ ).

In a multivariable analysis CsA starting dose of $5 \mathrm{mg} / \mathrm{kg} / \mathrm{d}$ (subdistribution hazard ratio [SHR]: $0.72,95 \% \mathrm{Cl}: 0.53-0.99 ; p=$ 0.045), use of ATG (SHR: $0.69,95 \% \mathrm{Cl}: 0.52-0.92 ; p=0.010$ ) and 
Table 1. Patient- and transplant-related characteristics of all patients $(n=519)$ and different cyclosporine therapy groups with $3 \mathrm{mg} / \mathrm{kg} / \mathrm{d} \mathrm{vs} .5 \mathrm{mg} /$ $\mathrm{kg} / \mathrm{d}$.

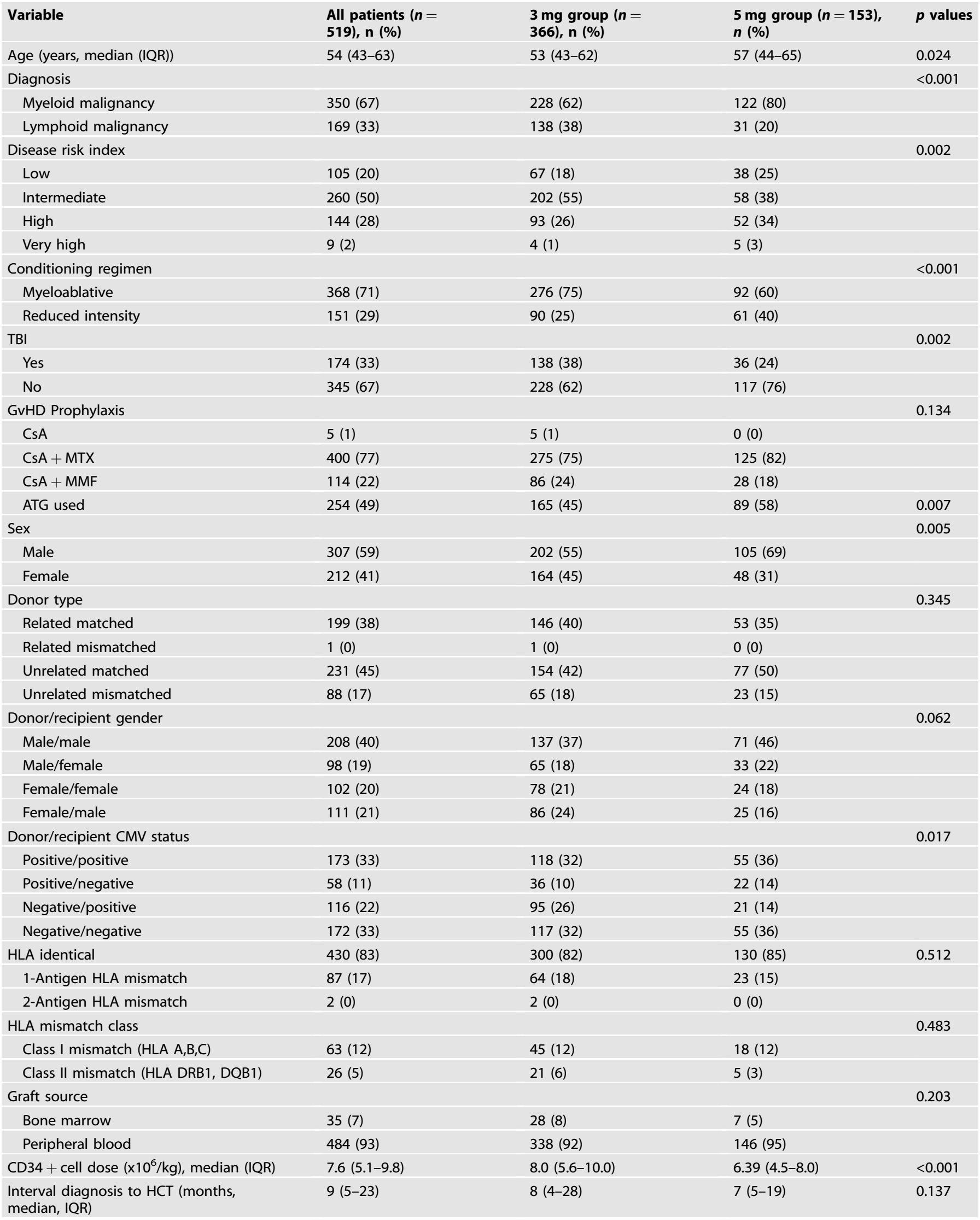


Table 1. continued

\begin{tabular}{|c|c|c|c|c|}
\hline Variable & $\begin{array}{l}\text { All patients }(n= \\
519), n(\%)\end{array}$ & $\begin{array}{l}3 \mathrm{mg} \text { group }(n= \\
366), \mathrm{n}(\%)\end{array}$ & $\begin{array}{l}5 \mathrm{mg} \text { group }(n=153), \\
n(\%)\end{array}$ & $p$ values \\
\hline $90-100 \%$ & $402(78)$ & 289 (79) & $113(74)$ & \\
\hline EBMT Score & & & & 0.790 \\
\hline $0-1$ & $22(4)$ & $16(4)$ & $6(4)$ & \\
\hline $\mathrm{HCT}-\mathrm{Cl}$ & & & & 0.853 \\
\hline $0-1$ & $312(60)$ & $220(60)$ & $92(60)$ & \\
\hline $2-4$ & $147(28)$ & $102(28)$ & $45(29)$ & \\
\hline$>4$ & $60(12)$ & $44(12)$ & $16(11)$ & \\
\hline
\end{tabular}

CMV Cytomegalovirus, CSA Cyclosporine A, EBMT European Group for Blood and Marrow Transplantation, GvHD Graft-versus-host disease, HCT Hematopoietic stem cell transplantation, HCT-Cl Hematopoietic cell transplantation comorbidity index, IQR Interquartile range, MMF Mycophenolate mofetil, MTX Methotrexate, KPS Karnofsky performance status, HLA Human leucocyte antigen, TBI Total body irradiation.

Table 2. HCT outcome within different CsA starting doses of $3 \mathrm{mg} / \mathrm{kg} / \mathrm{d}$ and $5 \mathrm{mg} / \mathrm{kg} / \mathrm{d}$.

\begin{tabular}{|c|c|c|c|}
\hline Variable & $3 \mathrm{mg} / \mathrm{kg}(\mathrm{n}=366)$ & $5 \mathrm{mg} / \mathrm{kg}(\mathrm{n}=153)$ & $p$ values \\
\hline aGvHD II-IV, d180 CIF (95\% Cl), \% & $41(36-46)$ & $33(26-40)$ & $0.043^{\mathrm{a}}$ \\
\hline aGvHD III-IV, d180 CIF (95\% CI), \% & $15(12-19)$ & $10(6-15)$ & $0.082^{\mathrm{a}}$ \\
\hline Acute GvHD steroid refractory, $n$ (\%) & $36(10)$ & $14(9)$ & 0.809 \\
\hline Primary graft failure (\%) & $11(3)$ & $2(1)$ & 0.435 \\
\hline 1-year CIF of cGvHD (95\% Cl), \% & $41(36-46)$ & $38(30-46)$ & $0.792^{\mathrm{a}}$ \\
\hline 1-year CIF of extensive cGvHD (95\% Cl), \% & $29(24-34)$ & $21(14-28)$ & $0.126^{\mathrm{a}}$ \\
\hline 1-year NRM CIF (95\% Cl), \% & $14(11-18)$ & $8(5-14)$ & $0.075^{\mathrm{a}}$ \\
\hline 1-year relapse CIF $(95 \% \mathrm{CI}), \%$ & $28(24-33)$ & $25(18-33)$ & $0.292^{\mathrm{a}}$ \\
\hline
\end{tabular}

Cl Confidence interval, CIF Cumulative incidence function, aGVHD Acute graft-versus-host disease, CGVHD Chronic graft-versus-host disease; HCT Hematopoietic cell transplantation, $d$ Day, NRM Non-relapse-related mortality, OS Overall survival, PFS Progression-free survival.

aderived univariable competing risk regression.

unrelated donor (SHR: 1.80, 95\% Cl: 1.33-2.45; $p<0.001$ ) were associated with incident aGvHD $\geq 2$ (Table 3 ).

\section{Cyclosporine starting doses and their levels post-allo HCT}

The comparison of median CsA levels within different CsA starting doses provide all over higher median CsA levels in the $5 \mathrm{mg} / \mathrm{kg} / \mathrm{d}$ CsA starting dose compared to $3 \mathrm{mg} / \mathrm{kg} / \mathrm{d}$ (Supplementary Table S2). In line with our previous data [36], we could confirm that aGvHD grade $\geq 2$ within different CsA cut offs of $50-99 \mu \mathrm{g} / \mathrm{L}$, $100-149 \mu \mathrm{g} / \mathrm{L}, 150-199 \mu \mathrm{g} / \mathrm{L}$ and $\geq 200 \mu \mathrm{g} / \mathrm{L}$ at day 10 after alloHCT was at lowest in patients with CsA levels greater or equal than $200 \mu \mathrm{g} / \mathrm{L}(p<0.001$; data not shown).

\section{Survival, NRM, and relapse rate}

As shown in Table 2 and Fig. 2, one-year OS was higher in the 5 $\mathrm{mg} / \mathrm{kg} / \mathrm{d}$ starting dose with $79 \%$ (95\% Cl: $71-85 \%)$ compared to patients with CsA $3 \mathrm{mg} / \mathrm{kg} / \mathrm{d}$ starting dose (70\% [95\% Cl: 65-74\%], respectively, $p=0.034)$. As shown, higher overall survival was associated with a non-significantly lower NRM incidence in the 5 $\mathrm{mg} / \mathrm{kg} / \mathrm{d}$ vs. $3 \mathrm{mg} / \mathrm{kg} / \mathrm{d}$ group with $8 \%$ (95\% Cl: 5-14\%) vs. 14 (95\% $\mathrm{Cl}: 11-18 \% ; p=0.075)$, respectively. Moreover, in the multivariable analyses we observed that a higher CsA starting dose and ATG use was associated with higher 1-year OS (adjusted HR 0.63; $95 \% \mathrm{Cl}$ : $0.41-0.95 ; p=0.027$ vs. adjusted HR $0.55 ; 95 \% \mathrm{Cl}: 0.39-0.78 ; p=$ 0.001 ), respectively (as depicted in Table 3 ). CIF of 1-year relapse and -PFS are shown in Table 2 and multivariable analyses for 1-year NRM and -relapse including, CsA starting doses, ATG use, donor type and DRI are shown in Table 3.

\section{DISCUSSION}

The GvHD is a frequent complication after allo-HCT with impact on morbidity and mortality $[4,5]$. Continuous and detailed investigations to optimize GvHD prophylaxis are warranted [12, 13]. Calcineurin inhibitors such as CsA have been the backbone of GvHD prophylaxis for decades [20, 21]. Despite long-term experience with $\mathrm{CsA}$, the optimal starting dose to achieve targeted CsA levels in the prevention of GvHD after allo-HCT is still unclear and thus an unmet clinical need $[23,24]$. Since previous studies showed that patients with higher CsA levels within the first few weeks post-HCT (ranging between 1 and 4 weeks) had lower incidence of GvHD [22, 26, 28, 36, 48], our study focused on different CsA starting doses of $3 \mathrm{mg} / \mathrm{kg} / \mathrm{d}$ vs. $5 \mathrm{mg} / \mathrm{kg} / \mathrm{d}$ on the incidence of GvHD after allo-HCT. There is some credibility to the fact that preventing GvHD is easier than to treat and that possibly early T-cell inhibition may be preferable [49]. Until 2016, the initial starting dose at our center was $3 \mathrm{mg} / \mathrm{kg} / \mathrm{d}$ targeting trough concentration $150-200 \mu \mathrm{g} / \mathrm{L}$ [50]. In spite of dose adjustments targeted CsA levels were insufficiently reached. Therefore, in 2016, the starting CsA dose was increased to $5 \mathrm{mg} / \mathrm{kg} / \mathrm{d}$ in order to 
reach appropriate CsA levels in a greater proportion of patients [36]. As a result, our data indicate that a higher proportion of individuals achieve targeted CsA levels (according previous analyses $>195 \mu \mathrm{g} / \mathrm{L}$ in the first 10 days after allo-HCT; [36]) with the higher starting dose of $5 \mathrm{mg} / \mathrm{kg} / \mathrm{d}$ compared to the starting dose of $3 \mathrm{mg} / \mathrm{kg} / \mathrm{d}$ [81/153 (53\%) vs. 147/363 (40\%), respectively; $p=0.009$, data not shown] and thus a potentially causal link with higher starting dose of CsA with $5 \mathrm{mg} / \mathrm{kg} / \mathrm{d}$ is likely. Moreover, for every $50 \mu \mathrm{g} / \mathrm{L}$ in level increase on day 10 after allo-HCT a decrease of the CIF of aGvHD was observed, i.e. there is a dose response gradient. Our results are in line with Rogosheske et al. [28] who showed that higher CsA levels above $200 \mathrm{ng} / \mathrm{mL}$, especially in the earlier period within the first two weeks post-transplantation contributed to lower risk of aGvHD.

In comparison to previous studies we found that the incidence of aGvHD was independent of conditioning regimen [17, 51, 52]. Ram et al. found in a large study that higher CsA levels in the first two weeks after allo-HCT lowered the risk of GvHD in patients receiving RIC conditioning regimes, but not in patients treated with MAC [27]. In contrast, Rogosheske et al. demonstrated after adjusting for CsA level, that the risk of aGvHD was similar in patients with different conditioning regimes [28]. Notably, in both studies, the starting dose in RIC was at day -3 with $5 \mathrm{mg} / \mathrm{kg} / \mathrm{d}$ (i.v.), while in MAC the CsA starting strategy was $3 \mathrm{mg} / \mathrm{kg} / \mathrm{d}$ at day -1

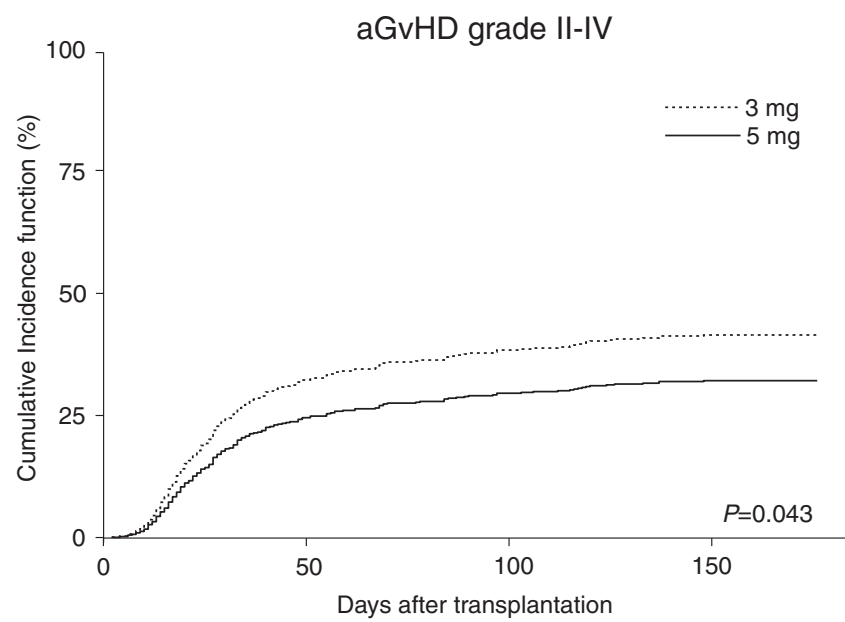

Fig. 1 Cumulative incidence function (CIF) of acute graft-versushost disease (aGvHD) grade II-IV. CIF of aGvHD grade II-IV in patients with $5 \mathrm{mg} / \mathrm{kg} / \mathrm{d}$ starting dose group (black line) compared to the $3 \mathrm{mg} / \mathrm{kg} / \mathrm{d}$ starting dose group (dashed line).
$[27,28]$. In contrast, in our study we start mostly CsA on day -3 in MAC, and on day -1 in RIC if fludarabine/low-dose TBI protocols were used. In line, we could show that the median of CsA levels after allo-HCT was higher in all patients with a starting dose of 5 $\mathrm{mg} / \mathrm{kg} / \mathrm{d}$, moreover this was also evident in patients treated within MAC protocols $(p=0.002$, data not shown). The results may indicate that a higher starting dose of $5 \mathrm{mg} / \mathrm{kg} / \mathrm{d}$ may overcome the potential negative effects of CsA starting dose in patients treated with CsA given at day -3 in MAC. Albeit, previous studies include different conditioning regimes, strategies to start CsA, our policy with higher starting doses on both MAC and RIC regardless of initiation, may explain in parts the independency of target trough CsA levels on aGvHD irrespective of conditioning regimens $[27,28]$.

Although several side effects of higher CsA levels were described in the literature $[25,53,54]$ and dose dependent CsA-related renal toxicity in previous studies are commonly developed, in line with de Kort et al. we found no renal impairment within different CsA starting doses and reached sufficient CsA levels within the first 7 days after allo-HCT [22]. Therefore, our results highlight that close monitoring of CsA levels can avoid renal toxicity also with higher CsA starting doses. Ongoing current investigations will include other side effects of dose depended CsA levels within different intensity of CsA starting doses.

Current studies highlight the promising role of post-transplant cyclophosphamide in combination with cyclosporine as a GvHD prophylaxis (e.g HLA mismatched unrelated donor) in allo-HCT. Whether higher CsA starting doses play a role in the context of post-transplant cyclophosphamide GvHD prophylaxis cannot be determined based on our data $[55,56]$.

Previous studies showed that higher CsA levels may have an impact on risk of NRM and OS [27, 28]. In contrast to previous studies $[22,26]$, we found that a higher starting dose with subsequent improved targeted CsA levels may be translated into a higher OS. This may be explained by a lack of power to detect differences or by confounding with variables not measured or observed.

This study has several limitations: Due to the observational nature of our study, treatments could not be allocated randomly. Secondly, we used a heterogeneous patient cohort with different hematological disorders, conditioning and GvHD prophylaxis regimens and duration of follow-up differed among groups. Heterogeneity with small numbers in certain subsets may reduce the generalizability of our results. In spite of careful adjustment in multivariable analysis demonstrating the superiority of the $5 \mathrm{mg} /$ kg starting dose, we cannot exclude unmeasured confounding.

Table 3. Uni- and multivariable competing risk or, where appropriate Cox regression analysis for aGvHD grade $\geq 2$, 1-year -NRM,- relapse and - overall survival for groups with differing CsA starting doses.

\begin{tabular}{|c|c|c|c|c|}
\hline \multirow[b]{2}{*}{ CSA starting dose $\mathrm{e}^{\mathrm{a}}$} & \multicolumn{2}{|c|}{ Univariable analysis } & \multicolumn{2}{|c|}{ Multivariable analysis } \\
\hline & SHR/HR (95\% CI) & $p$ value & SHR/HR (95\% CI) & $p$ value \\
\hline aGVHD grade II-IV ${ }^{b}$ & $0.72(0.53-0.98)$ & 0.043 & $0.72(0.53-0.99)$ & 0.045 \\
\hline 1-year relapse $\mathrm{d}^{\mathrm{d}}$ & $0.82(0.56-1.19)$ & 0.296 & $0.78(0.53-1.15)$ & 0.206 \\
\hline 1-year overall survival ${ }^{\mathrm{e}}$ & $0.64(0.43-0.97)$ & 0.035 & $0.63(0.41-0.95)$ & 0.027 \\
\hline
\end{tabular}

Number of subjects included in the univariable and multivariable model $n=519$.

Cl Confidence interval, CSA Cyclosporine A, DRI Disease risk index, aGVHD Acute graft-versus-host disease, HCT Hematopoietic cell transplantation, SHR Subhazard ratio, RIC Reduced intensity conditioning, NRM Non-relapse mortality.

$\mathrm{a}_{3} \mathrm{mg} / \mathrm{kg}$ starting dose is baseline $\mathrm{HR}=1$.

${ }^{\mathrm{b}}$ model adjusted for DRI, donor type, ATG use.

' model adjusted for DRI, donor type, ATG use.

${ }^{d}$ model adjusted for DRI, donor type, ATG use.

emodel adjusted for ATG use, DRI, donor type. 


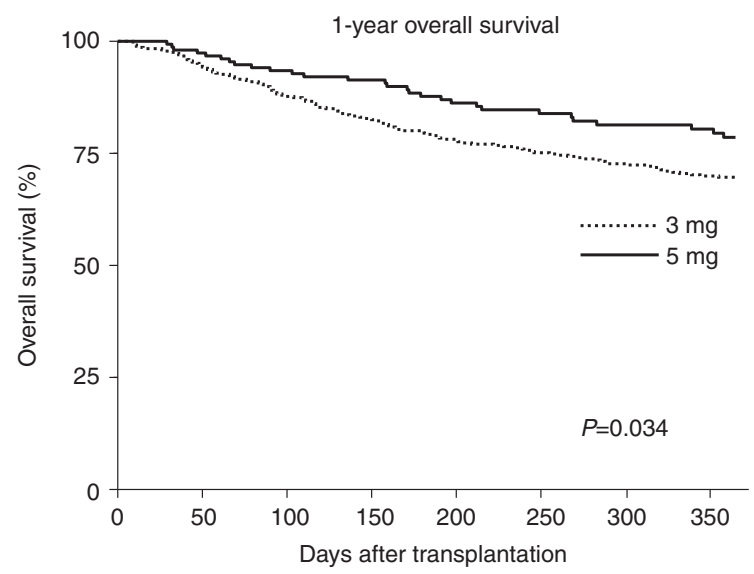

Number at risk

$\begin{array}{lllllllll}3 \mathrm{mg} & 366 & 347 & 321 & 303 & 286 & 275 & 266 & 256 \\ 5 \mathrm{mg} & 153 & 149 & 138 & 127 & 115 & 101 & 90 & 87\end{array}$

Fig. 2 Kaplan-Meier curve for overall survival (OS). One-year OS for CsA $5 \mathrm{mg} / \mathrm{kg} / \mathrm{d}$ starting dose group (black line) compared to the CsA $3 \mathrm{mg} / \mathrm{kg} / \mathrm{d}$ starting dose group (dashed line).

In conclusion, our results indicate that a higher CsA starting dose of $5 \mathrm{mg} / \mathrm{kg} / \mathrm{d}$ may increase the proportion of patients with desired CsA levels after allo-HCT, which was a preventive factor of incident aGvHD. These results underline the importance of reaching sufficient $\mathrm{Cs} A$ levels within an early time period following allo-HCT. If these data are confirmed, recommendations as to starting doses currently at $3 \mathrm{mg} / \mathrm{kg} / \mathrm{d}$ may be amended.

\section{REFERENCES}

1. Potdar R, Varadi G, Fein J, Labopin M, Nagler A, Shouval R. Prognostic scoring systems in allogeneic hematopoietic stem cell transplantation: where do we stand? Biol Blood Marrow Transpl. 2017;23:1839-46.

2. Copelan EA. Hematopoietic stem-cell transplantation. $N$ Engl J Med. 2006;354:1813-26.

3. Passweg JR, Baldomero H, Bader P, Bonini C, Duarte RF, Dufour C, et al. Use of haploidentical stem cell transplantation continues to increase: the 2015 European Society for Blood and Marrow Transplant activity survey report. Bone Marrow Transpl. 2017;52:811-7.

4. Gooley TA, Chien JW, Pergam SA, Hingorani S, Sorror ML, Boeckh M, et al. Reduced mortality after allogeneic hematopoietic-cell transplantation. $\mathrm{N}$ Engl J Med. 2010;363:2091-101.

5. McDonald GB, Sandmaier BM, Mielcarek M, Sorror M, Pergam SA, Cheng GS, et al. Survival, nonrelapse mortality, and relapse-related mortality after allogeneic hematopoietic cell transplantation: comparing 2003-2007 -versus 2013-2017 cohorts. Ann Intern Med 2020;172:229-39.

6. Tomblyn M, Chiller T, Einsele H, Gress R, Sepkowitz K, Storek J, et al. Guidelines for preventing infectious complications among hematopoietic cell transplant recipients: a global perspective. Pref Bone Marrow Transpl. 2009;44:453-5.

7. Nurnberger W, Willers R, Burdach S, Gobel U. Risk factors for capillary leakage syndrome after bone marrow transplantation. Ann Hematol. 1997;74:221-4.

8. Mohty M, Malard F, Abecassis M, Aerts E, Alaskar AS, Aljurf M, et al. Revised diagnosis and severity criteria for sinusoidal obstruction syndrome/veno-occlusive disease in adult patients: a new classification from the European Society for Blood and Marrow Transplantation. Bone Marrow Transpl. 2016;51:906-12.

9. Hingorani S, Guthrie KA, Schoch G, Weiss NS, McDonald GB. Chronic kidney disease in long-term survivors of hematopoietic cell transplant. Bone Marrow Transpl. 2007;39:223-9.

10. Dalle JH, Giralt SA. Hepatic veno-occlusive disease after hematopoietic stem cell transplantation: risk factors and stratification, prophylaxis, and treatment. Biol Blood Marrow Transpl. 2016;22:400-9.

11. Cooke KR, Yanik G. Acute lung injury after allogeneic stem cell transplantation: is the lung a target of acute graft-versus-host disease? Bone Marrow Transpl. 2004;34:753-65.

12. Zeiser R, Blazar BR. Acute graft-versus-host disease - biologic process, prevention, and therapy. N Engl J Med. 2017;377:2167-79.

13. Zeiser R, Blazar BR. Pathophysiology of chronic graft-versus-host disease and therapeutic targets. N Engl J Med. 2017;377:2565-79.
14. Gerull S, Arber C, Bucher C, Buser A, Gratwohl A, Halter J, et al. Cyclosporine levels and rate of graft rejection following non-myeloablative conditioning for allogeneic hematopoietic SCT. Bone Marrow Transpl. 2011;46:740-6.

15. Lee SE, Cho BS, Kim JH, Yoon JH, Shin SH, Yahng SA, et al. Risk and prognostic factors for acute GVHD based on NIH consensus criteria. Bone Marrow Transpl. 2013;48:587-92.

16. Flowers ME, Inamoto $\mathrm{Y}$, Carpenter PA, Lee SJ, Kiem HP, Petersdorf EW, et al. Comparative analysis of risk factors for acute graft-versus-host disease and for chronic graft-versus-host disease according to National Institutes of Health consensus criteria. Blood 2011;117:3214-9.

17. Jagasia M, Arora M, Flowers ME, Chao NJ, McCarthy PL, Cutler CS, et al. Risk factors for acute GVHD and survival after hematopoietic cell transplantation. Blood 2012;119:296-307.

18. Saliba RM, de Lima M, Giralt S, Andersson B, Khouri IF, Hosing C, et al. Hyperacute GVHD: risk factors, outcomes, and clinical implications. Blood 2007;109:2751-8.

19. Gupta A, Punatar S, Gawande J, Mathew L, Kannan S, Khattry N. Analysis of factors affecting initial cyclosporine level and its impact on post transplant outcomes in acute leukemia. J Cancer Res Ther. 2017;13:981-8.

20. Bolwell B, Sobecks R, Pohlman B, Andresen S, Rybicki L, Kuczkowski E, et al. A prospective randomized trial comparing cyclosporine and short course methotrexate with cyclosporine and mycophenolate mofetil for GVHD prophylaxis in myeloablative allogeneic bone marrow transplantation. Bone Marrow Transpl. 2004;34:621-5.

21. Choi SW, Reddy P. Current and emerging strategies for the prevention of graftversus-host disease. Nat Rev Clin Oncol. 2014;11:536-47.

22. de Kort EA, de Lil HS, Bremmers MEJ, van Groningen LFJ, Blijlevens NMA, Huls G, et al. Cyclosporine A trough concentrations are associated with acute GvHD after non-myeloablative allogeneic hematopoietic cell transplantation. PLoS One. 2019;14:e0213913.

23. Bhatt V, Lin A, Beyer K, Proli A, Yoo Y, Ponce D, et al. Analysis of cyclosporine A levels supports new dosing guidelines in adult double-unit cord blood transplant recipients to optimize immunosuppression early post-transplant. Biol Blood Marrow Transpl. 2016;22:1533-4.

24. Kedmi M, Dray L, Grisariu S, Resnick IB, Stepensky P, Aker M, et al. The effect of cyclosporine initiation time on the outcome of matched allogeneic stem-cell transplantation following fludarabine-based conditioning. Transpl Int. 2012;25:1241-7.

25. Kishi Y, Murashige N, Kami M, Miyakoshi S, Shibagaki Y, Hamaki T, et al. Optimal initial dose of oral cyclosporine in relation to its toxicities for graft-versus-host disease prophylaxis following reduced-intensity stem cell transplantation in Japanese patients. Bone Marrow Transpl. 2005;35:1079-82.

26. Malard F, Szydlo RM, Brissot E, Chevallier P, Guillaume T, Delaunay J, et al. Impact of cyclosporine-A concentration on the incidence of severe acute graft-versushost disease after allogeneic stem cell transplantation. Biol Blood Marrow Transpl. 2010;16:28-34.

27. Ram R, Storer B, Mielcarek M, Sandmaier BM, Maloney DG, Martin PJ, et al. Association between calcineurin inhibitor blood concentrations and outcomes after allogeneic hematopoietic cell transplantation. Biol Blood Marrow Transpl. 2012;18:414-22.

28. Rogosheske JR, Fargen AD, DeFor TE, Warlick E, Arora M, Blazar BR, et al. Higher therapeutic CSA levels early post transplantation reduce risk of acute GVHD and improves survival. Bone Marrow Transpl. 2014;49:122-5.

29. Zeighami S, Hadjibabaie M, Ashouri A, Sarayani A, Khoee SH, Mousavi S, et al. Assessment of cyclosporine serum concentrations on the incidence of acute graft versus host disease post hematopoietic stem cell transplantation. Iran J Pharm Res. 2014;13:305-12.

30. Inoue Y, Saito T, Ogawa K, Nishio Y, Kosugi S, Suzuki Y, et al. Pharmacokinetics of cyclosporine $A$ at a high-peak concentration of twice-daily infusion and oral administration in allogeneic haematopoietic stem cell transplantation. J Clin Pharm Ther. 2011;36:518-24.

31. Furukawa T, Kurasaki-lda T, Masuko M, Tsukada N, Okazuka K, Sato N, et al. Pharmacokinetic and pharmacodynamic analysis of cyclosporine A (CsA) to find the best single time point for the monitoring and adjusting of CsA dose using twice-daily 3-h intravenous infusions in allogeneic hematopoietic stem cell transplantation. Int J Hematol. 2010;92:144-51.

32. Kimura S, Oshima K, Okuda S, Sato K, Sato M, Terasako K, et al. Pharmacokinetics of CsA during the switch from continuous intravenous infusion to oral administration after allogeneic hematopoietic stem cell transplantation. Bone Marrow Transpl. 2010;45:1088-94.

33. Capone D, De Marino V, Fontana R, Notaro R, De Marino V, Pisanti N. Effects of different routes of cyclosporin $A$ administration on blood levels in patients undergoing bone marrow transplantation. Bone Marrow Transpl. 1997;19:369-72.

34. Storb R, Deeg HJ, Whitehead J, Appelbaum F, Beatty P, Bensinger W, et al. Methotrexate and cyclosporine compared with cyclosporine alone for prophylaxis of acute graft versus host disease after marrow transplantation for leukemia. N Engl J Med. 1986;314:729-35. 
35. Carreras E, Dufour C, Mohty M, Kröger N, (eds). The EBMT Handbook: Hematopoietic Stem Cell Transplantation and Cellular Therapies. 7th edn. Springer: Cham, CH, 2019.

36. Bianchi M, Heim D, Lengerke C, Halter J, Gerull S, Kleber M, et al. Cyclosporine levels $>195 \mathrm{mug} / \mathrm{L}$ on day 10 post-transplant was associated with significantly reduced acute graft-versus-host disease following allogeneic hematopoietic stem cell transplantation. Ann Hematol. 2019;98:971-7.

37. Park S, Kim K, Jang JH, Kim SJ, Kim WS, Jung CW. Blood concentration of cyclosporine during early post-transplant period may have influence on the occurrence of chronic graft versus host disease in patients who received allogeneic hematopoietic stem cell transplantation. Oncotarget 2016;7:59892-901.

38. Gratwohl A. The EBMT risk score. Bone Marrow Transpl. 2012;47:749-56.

39. Sorror ML, Maris MB, Storb R, Baron F, Sandmaier BM, Maloney DG, et al. Hematopoietic cell transplantation (HCT)-specific comorbidity index: a new tool for risk assessment before allogeneic HCT. Blood 2005;106:2912-9.

40. Armand P, Gibson CJ, Cutler C, Ho VT, Koreth J, Alyea EP, et al. A disease risk index for patients undergoing allogeneic stem cell transplantation. Blood 2012;120:905-13.

41. Levey AS, Stevens LA. Estimating GFR using the CKD Epidemiology Collaboration (CKD-EPI) creatinine equation: more accurate GFR estimates, lower CKD prevalence estimates, and better risk predictions. Am J Kidney Dis. 2010;55:622-7.

42. Levey AS, Stevens LA, Schmid CH, Zhang YL, Castro AF 3rd, Feldman HI, et al. A new equation to estimate glomerular filtration rate. Ann Intern Med. 2009;150:604-12.

43. Binkert L, Medinger M, Halter JP, Heim D, Gerull S, Holbro A, et al. Lower dose anti-thymocyte globulin for GvHD prophylaxis results in improved survival after allogeneic stem cell transplantation. Bone Marrow Transpl. 2015;50:1331-6.

44. Przepiorka D, Weisdorf D, Martin P, Klingemann HG, Beatty P, Hows J, et al. 1994 consensus conference on acute GVHD grading. Bone Marrow Transplant 1995;15:825-8.

45. Lee SJ, Vogelsang G, Flowers ME. Chronic graft-versus-host disease. Biol Blood Marrow Transpl. 2003;9:215-33.

46. Ruutu T, van Biezen A, Hertenstein B, Henseler A, Garderet L, Passweg J, et al. Prophylaxis and treatment of GVHD after allogeneic haematopoietic SCT: a survey of centre strategies by the European Group for Blood and Marrow Transplantation. Bone Marrow Transpl. 2012;47:1459-64.

47. Fine JP, Gray RJ. A proportional hazards model for the subdistribution of a competing risk. J Am Stat Assoc. 1999;94:496-509.

48. Yee GC, Self SG, McGuire TR, Carlin J, Sanders JE, Deeg HJ. Serum cyclosporine concentration and risk of acute graft-versus-host disease after allogeneic marrow transplantation. N. Engl J Med. 1988;319:65-70.

49. Reddy P, Socie G, Cutler C, Weisdorf D. GVHD prevention: an ounce is better than a pound. Biol Blood Marrow Transpl. 2012;18:S17-26. 1 Suppl.

50. Carreras E, Dufour C, Mohty M, Kröger N, (eds). The EBMT Handbook: Hematopoietic Stem Cell Transplantation and Cellular Therapies. 7th edn. Springer: Cham, CH, 2019.

51. Couriel DR, Saliba RM, Giralt S, Khouri I, Andersson B, de Lima M, et al. Acute and chronic graft-versus-host disease after ablative and nonmyeloablative conditioning for allogeneic hematopoietic transplantation. Biol Blood Marrow Transpl. 2004;10:178-85.

52. Mielcarek M, Martin PJ, Leisenring W, Flowers ME, Maloney DG, Sandmaier BM, et al. Graft-versus-host disease after nonmyeloablative versus conventional hematopoietic stem cell transplantation. Blood 2003;102:756-62.

53. Klintmalm G, Sawe J, Ringden O, von Bahr C, Magnusson A. Cyclosporine plasma levels in renal transplant patients. Association with renal toxicity and allograft rejection. Transplantation. 1985;39:132-7.
54. Naesens M, Kuypers DR, Sarwal M. Calcineurin inhibitor nephrotoxicity. Clin J Am Soc Nephrol. 2009;4:481-508.

55. Battipaglia G, Labopin M, Kroger N, Vitek A, Afanasyev B, Hilgendorf I, et al. Posttransplant cyclophosphamide vs antithymocyte globulin in HLA-mismatched unrelated donor transplantation. Blood 2019;134:892-9.

56. Soltermann Y, Heim D, Medinger M, Baldomero $H$, Halter JP, Gerull $S$, et al. Reduced dose of post-transplantation cyclophosphamide compared to ATG for graft-versus-host disease prophylaxis in recipients of mismatched unrelated donor hematopoietic cell transplantation: a single-center study. Ann Hematol. 2019;98:1485-93.

\section{AUTHOR CONTRIBUTIONS}

$\mathrm{JH}, \mathrm{JRP}$ and MK designed research, performed research, analyzed data and wrote the paper. $\mathrm{MM}$ and $\mathrm{HB}$ contributed to data extraction, analyzed data and wrote the paper. CA, DH and JPH analyzed data and wrote the paper.

\section{FUNDING}

Open access funding provided by University of Basel.

\section{COMPETING INTERESTS}

The authors declare no competing interests.

\section{ADDITIONAL INFORMATION}

Supplementary information The online version contains supplementary material available at https://doi.org/10.1038/s41409-022-01598-6.

Correspondence and requests for materials should be addressed to Martina Kleber.

Reprints and permission information is available at http://www.nature.com/ reprints

Publisher's note Springer Nature remains neutral with regard to jurisdictional claims in published maps and institutional affiliations.

(i) Open Access This article is licensed under a Creative Commons adaptation, distribution and reproduction in any medium or format, as long as you give appropriate credit to the original author(s) and the source, provide a link to the Creative Commons license, and indicate if changes were made. The images or other third party material in this article are included in the article's Creative Commons license, unless indicated otherwise in a credit line to the material. If material is not included in the article's Creative Commons license and your intended use is not permitted by statutory regulation or exceeds the permitted use, you will need to obtain permission directly from the copyright holder. To view a copy of this license, visit http://creativecommons. org/licenses/by/4.0/.

(c) The Author(s) 2022 